\title{
161. Some Confirmatory Light upon the Records of Kirishitan Missions from Japanese Sources.
}

\section{The Omura Documents.}

\author{
By Masaharu ANES : KI, \\ Tokyo Imperial University, \\ and \\ Kazuhiko TaKamuro, \\ Omura Niddle School.
}

(Comm. by M. A NESAKI, M.I.A., Nov. 12, 1927.)

As legends, documents, relics are coming to light from various localities and sources, the stories of the Catholic missions, particularly of martyrdoms, as reported in the missionary records are confirmed more and more by the materials from Japanese sources.

One of these Japanese sources is a collection of legends and copies of documents made early in the nineteenth century by a scholar in Omura, once a stage of furious persecutions. Its title is "Kenmonshu " (見聞集) “What has been seen and heard," and has been preserved in the Omura family and is now deposited in the Omura Middle School.

The part referred to in this report is taken from the 13th volume containing copies of twenty official documents of correspondence between the governors of Nagasaki and the officials of the Omura fief, ranging in the years 1627 and 1637 . Besides a document from 1619 is found in the 11th volume. Some important ones shall here be cited, all the dates being given in the Gregorian equivalents.

1) A report sent from Omura to Nagasaki, dated May 4, 1619. Since the issue, in 1617, of an order to enforce persecution, two Padres captured earlier, two others captured later (one of them, of the Compagnia), and one Irman were executed, while two Padres, three Irmans and two Dojikus (Catechists) were still in prison.

This execution referes to the martydoms, first, of J.-B. Machado (S.J.) and Pedro de l'Assumpcion (F.M.), on May 22nd, 1617, at Kori near Omura (Pagés, 353-55), and, second, of Alonso de Navarette 
(O.P.), Hernando de S. Joseph (Augustin), and Leon Tonaca, the Catechist, on June 1, 1617, at Takashima in the Bay of Omura (Pagés, $363-66$ ).

The two fathers imprisoned were evidently Apollinaire Franco, arrested on July 7, and Thomas de Zumarraga, arrested on July 24, 1617 (Pagés, 368), while the five others can partially be identified.

2) A receipt sent from Omura to Nagasaki, dated July 4, 1633, the most interesting of the documents, contains the names of those arrested and entrusted to imprisonment in Omura. The names of the prisoners, identified with those in the missionary records, are:-

Domingo de Erquicia (Japanese name, Tayemon) and his two catechists (Pagés, 789) arrested at Nagayo.

Francisco de Gracia (Jap. name, Yohyoye), his two catechists and their boatman Kansuke (Pagés, 787-88) arrested at Amegora (雨ヶ浦).

Giacomo Antonio Giannone (Jap. name, Hosai 法流) and his catechist Kuhyoye, probably Juan Kidera (Pagés, 788), arrested at Kazusa in Takaku.

Manoel Borges (Jap. name, Higashi Jiroyemon 束次鄓右街阴) and his two catechists (Pagés. 787) arrested in the territory of Saeki, Bungo.

Diego de S. Maria, the Japanese Dominican Gorobyioye (五郎兵微), and his catechist (Pagés, 785) arrested at Tomachi (外町 or F町) in Nagasaki.

Shiroyemon, the Irman at Fudoyama (不動山), arrested in the same place, probably Nicola Keian Soucounaga (Pagés, 434).

Some of the names of the catechists can be identified. The interesting point in this document is that every one of the Padres bore a Japanese name not mentioned in the missionary records.

3) A receipt sent from Omura to Nagasaki dated July 31,1633 , of the five imprisoned :-

Bento Fernandez (Jap. name, Sukenojo 助之方) and his two catechists, one of whom is Luis Cafoucou (Pagés, 791-93); Paul Saito (Jap. name, Shozayemon 小左街阴) and his catechist (Pagés, 790-93).

4) A notification from the governors of Nagasaki to Omura, dated Aug. 10, 1633, asking to send to Nagasaki within two days Domingo de Erquicia, his catechist Shoyemon, Manoel Borges, his two catechists, while one of Erquicia's two catechists, Mozayemon, is to be executed at Omura (see below). The missionary records tell that Borges expired in pit on Aug. 16 (Pagés, 787) and Erquicia on Sep. 1. (Pagés, 789), both at Nagasaki. 
5) A similar note dated Aug. 11, to send Giannone and his catechist to Nagasaki. He expired on Aug. 28 at Shimabara (Pagés, 788-89). The receipt of the two convoys is dated Aug. 12.

6) A testimony by the deputies from Nagasaki, dated Aug. 27, that they witnessed the execution that morning at Omura. The persons executed, burnt alive, were four :-

Mozayemon, the host of Erquicia.

Ichibyoye, the host of Francisco de Gracia.

Kansuke, the boatman.

A woman Irman.

Here there are discrepencies from the statements in Pagés (788 and note).

7) A note and a receipt concerning Bento Fernandez, Paul Saito, and their three catechists, dated Aug. 16 and 18. The two Padres, according to Pagés (792-93), were put into pit on Sept. 25.

8) Two notes sent to Omura by the governors of Nagasaki from Hakata, dated Dec. 7 and 13, concerning a Padre arrested at the mouth of the great river of Osaka and sent to Hakata. This Padre was Sebastian Vieyra (Pagés, 786).

9) A receipt sent from Omura to Nagasaki, dated Dec. 29, on the delivery of Basiraan Beira (certainly Sebastian Vieyra).

10) A note requesting the convoy from Omura to Nagasaki of the Padre sent from Hakata (i.e. Vieyra) and two Padres sent from Bizen, dated Jan. 13, 1634. These latter may be the two cited below.

11) A note sent from Nagasaki to Omura requesting despatch of authoritative officials for entrusting to them two Padres, dated Aug. 12, 1634. Probably these two mean Giordano di S. Stefano and Thomas de S. Jacinthe (Pagés 807).

12) Two statements made by local officials concerning the pursuit of five boatmen, dated Aug. 17 and 18, 1627. The five are Juan (of Tokitsu), Thome, Seijiro and Adam (of Nagaura), and Jacob (of Miye), all boatmen. No clue to these names is found in the missionary records.

13) A statement presented to the authorities concerning the "Padre" Jihyoye and his companion Yoichiro, by the latter's relatives, dated Dec. 15, 1635. Exciting stories are told in this collection and some other sources about the pursuit and arrest of Jihyoye in 1635-37 but no clue is found in the missionary record. 